\title{
TRANSGRESSING URBAN UTOPANISM: AUTONOMY AND ACTIVE DESIRE
}

by

Rhiannon Firth

FIRTH, R. (2012): 'Transgressing urban utopanism: autonomy and active desire', Geografiska Annaler: Series B, Human Geography 94 (...): ...-... .

ABSTRACT. It has been extensively argued by theorists of liberal globalization as well as by radical theorists such as situationists and anarchists, that as the site of the concentration of capital, the city is the primary site for the formation of new subjectivities, new rights-claiming practices and the intensification of resistance as the starting point for an alternative, inclusionary urban citizenship. This article contends that by dismissing or separating rural and agricultural practices, such theories express a contradiction that can best be understood not as a struggle between rural and urban utopias, but between two different approaches to utopianism - hegemonic, associated with statist practices; and critical, associated with autonomous practices. The article considers emergent free spaces within UK, including intentional communities, autonomous social centres, radical housing co-operatives and eco-villages, both in urban and rural areas, as specific instances of materialized utopias that are becoming-autonomous, allowing us to think beyond dominant spatial formations by offering alternative futures whilst simultaneously engaging in resistant practices in the present. Voices of interviewed practitioners and observations of practices in these spaces are brought into dialogue with theory, highlighting gaps and weaknesses and opening space for further theorizing and new imaginings. This offers possibilities for a criticalautonomous conception of utopianism that does not take existing spatial formations for granted.

Keywords: autonomy, utopia, urbanism, desire, praxis, rural 


\section{Introduction}

The city is often a site of utopian practices, but is it right to conflate spatial utopianism with urban spaces? Across a range of diverse authors, the urban is taken as the privileged site for utopian contestation or for actualizing new, alternative forms of citizenship and belonging. There are, indeed, a wide range of transgressive utopian practices which are located in urban spaces. But should one generalize from such examples to render the city as the locus of utopianism per se? This article will argue that utopia is not exclusively an attribute of cities, but rather, that it inheres in the construction of relational autonomy. This often requires the subversion of the urban-rural division to construct immanence in social spaces. The difficulty with urban utopias is that, in privileging the urban site, they fail to deconstruct dominant spatial formations and hence reproduce the alienation of space in capitalist macro-geographies. It therefore follows that utopias should not accept the reified binaries of an alienated social reality, but rather, that the utopian function consists precisely in problematizing and transgressing the boundaries of reified conceptions of spatial organization.

My objectives in the article are threefold. First, to develop a theoretical framework of critical utopianism informed by the post-structuralist concept of active desire and by the praxis of autonomy, to contribute to geographical, political theory and broader interdisciplinary literatures on utopia. Second, to apply this theoretical framework to one particular area of spatial theory in a critique of utopian urbanism, to show that the active articulation of desire suggested by autonomous utopianism lies in the deconstruction of set spatial constructs such as the urban-rural divide. Third, to argue that a fundamental aspect of the approach involves attention to practices of autonomy, which introduce a further element of contingency, critique and transgression. In the empirical section, I explore how desire intersects with intent in more-or-less politicized spatialities in the United Kingdom, including intentional communities, autonomous social centres, radical housing co-operatives and eco-villages (the categories often overlap), in both urban and rural areas. As specific instances of materialized utopias that are becoming-autonomous, such examples encourage one to think beyond dominant spatial formations by 
offering alternative futures whilst simultaneously engaging in resistant practices in the present. The article concludes by arguing that utopia as the active affirmation of desire should not be seen as an attribute of fixed spatialities, but is rather expressed through practices of autonomy which fundamentally disrupt set spatial forms through processes of dis-alienation and immanence.

\section{Critical utopianism and the affirmation of desire}

Like most interesting political concepts utopia is difficult to define. In terms of a preliminary etymology, the term comes from More's ([1516] 2004) pun on the Greek eutopia meaning 'good place' and outopia meaning 'no place' (Taylor 2003, p. 554), thus 'the primary characteristic of the utopian place is its nonexistence combined with topos - a location in time and space - to give verisimilitude' (Sargent 1994, p. 5). Utopias and utopianism are best defined functionally, as articulating critique and dissatisfaction (with the present frame or status quo) as well as desire, for something better (Levitas 1990).

This article is an exercise in critical utopianism, looking in particular at the spatial dimension of utopian transformation. It explores utopian practices that challenge dominant spatial discourses and forms. The methodology used herein stems from a larger project on autonomous spaces as actualizations of a critical utopian impulse that allows one to explore simultaneously the processes of theory-production and practical transformation (Firth 2011), and is based in an interdisciplinary tradition of scholarship on utopias and utopianism particularly emerging from the work of Ernst Bloch (1986), and continuing through more recent 'critical' and 'transgressive' utopianisms of Tom Moylan (1986) and Lucy Sargisson $(1996,2000)$. The approach envisages that the utopian impulse is not confined to social engineers, but rather is endemic to everyday life (Gardiner 2004). This suggests a methodology of interpreting (some) utopias not as blueprints but as explorations and articulations of the process of desiring-production (Deleuze and Guattari 2004, p. 35), thus dividing utopias into two different functional types. On the one hand, we have the utopias of dominant ideologies such as neo-liberalism and conservatism (Levitas 1990, p. 188) as well as the counter-hegemonic utopias of Marxism (Day 
2005), which are based upon truth-claims and specific assumptions about human nature and can have totalizing effects. On the other hand we have utopias which are fictive, playful or experimental articulations of the imagination, to be found for example in the theories of Nietzsche (McManus 2005) or in those fictional or practiced utopias which are self-critical and reflexive, and contain internal processes for the articulation of multiple different hopes and desires (Moylan 1986, p. 28; Sargisson 1996, 2000). A similar distinction is drawn by Bell who describes one tradition of utopianism that is driven by a desire for freedom and another driven by a desire for order (Bell 2010, p. 7; see also Berneri 1950, p. 2).

Critical utopianism is based on a certain intentionality at the level of desire, and usually, but not necessarily, a particular utopian intent. The emphasis on desire focuses on the functioning of utopias as 'machines', in the Deleuzian sense of assemblages of forces or affects (Deleuze and Guattari 2004, pp. 36-37) rather than their explicit intent. This reflects a current concern in critical geographic and cultural studies literatures. Garforth argues that contemporary utopian theory problematizes intention since this implies fixed goals and closure, and is thus associated with 'the totalising, the authoritarian, the static, the final' (Garforth 2009, p. 21). Thus theorists such as Ben Anderson have viewed utopia as something which can be little more than a transitory affect, actuated through environmental media such as music which are experienced in the everyday. Experiences of hope can thus give fleeting impressions of Utopia as an excess or outside of the present (Anderson 2008, p. 743). Similarly, Kraftl (2007) has examined how architectural notions of the 'unhomely' and 'unsettling' can disrupt fixed notions of the good life and can thus become affectively utopian and transformative. In this 'turn to affect', Garforth argues that 'What is valued here (as utopian?) is becoming itself, severed from outcomes or goals - change and difference and process (means) become endless ends in themselves' (Gartforth 2009, pp. 19 and 20, respectively).

Garforth is right to argue that utopia need not always be intentional, and I would concur with her preference for critical, open-ended utopias rather than those that imply closure. Nonetheless, I do think 
that the notion of political agency is important in some utopias, whilst acknowledging that open-ended utopias imply a different degree and kind of agency and intent than closed ones. One type of utopia (or utopian function) which is both intentional, as a collective expression of desire for a better way of being, but does not imply totalizing politics, blueprinting or closure, is the praxis of autonomy. Autonomy is a process of dis-alienation which must first be understood as the affirmation of active desire. In recent political theory literatures, particularly post-left anarchist literature and post-structuralism, a similar distinction to that discussed above is often drawn between fixed utopias, or utopias of form, and those utopias which are propulsive, immanent or prefigurative (Bonanno 1988; Anon 1999; Anon 2001; Robinson and Tormey 2009). It is the latter case which expresses utopianism as transformative and desire-affirmative phenomenon. The idea of active desire drawn from Deleuze ([1983] 2006) and elaborated by Perez (1990) and Karatzogianni and Robinson (2010), is often associated with the drive for autonomy and offers a useful addition to a framework for understanding immanent utopianism.

Not every desire or hope is utopian in an autonomous sense. Active desire involves a direct connection to other forces through flows and assemblages (Deleuze [1983] 2006), p. 45). Active desire is desire which is directly connected with its object (Deleuze [1983] 2006, p. 45; Karatzogianni and Robinson 2010, p. 15) whereas reactive desire is alienated desire which contains 'both a repressed and a repressive content' and hence is 'mediated and indirect' (Karatzogianni and Robinson 2010, p. 15). Reactive desire involves the inscription of organization and command onto immanence (Perez 1990, pp. 18-19) whereas active desire is associated with the articulation of difference and the desire for transformation, including self-transformation, the transformation of set thought-patterns and concepts and of the world and exteriority through direct connection (Karatzogianni and Robinson 2010, p. 16; Deleuze [1983] 2006, p. 54). '[O]nly active force asserts itself, it affirms its difference and makes its difference an object of affirmation' (Deleuze [1983] 2006, pp. 55-56). Reactive desire is active desire which is turned against itself, so it comes to desire its own repression (Deleuze [1983] 2006, p. 61). It is 
on the back of reactive desire that the anti-utopian forces of representation and mediation enter social life. Reactive desire is the enslavement of desire by sovereignty, whereas active desire is the overthrow of sovereignty (Deleuze and Guattari 2004, p. 366). A utopia of reactive desire would be a 'space of laws', 'neat and orderly' (Perez 1990, pp. 18-19), and reactive desire might use supplementary hope to sustain submission to the renunciation of active desire. In contrast, projects of autonomy are based on active desire as an explicit or implicit motive-force for forms of life. Active desire subordinates social production - the social production of meaning as well as production in the economic realm - to desiring-production; 'the productive flows of desire at a molecular level, in which networks of connections are formed' (Karatzogianni and Robinson 2010, p. 17). A utopia of active desire 'follows the lines of escape of desire; breaches the wall and causes flows to move; assembles its machines and its groups-in-fusion in the enclaves or at the periphery' (Deleuze and Guattari 2004, p. 277).

Later in this article I will consider how dis-alienation as the breaking down of alienated relationships and their replacement with immediate relationships relates to the urban-rural divide, and how spatial forms might be (and sometimes are) dis-alienated through the production of autonomy in practice. At this point, however, I would like to further theorize the relationship between utopia, active desire and autonomy to form a methodological basis for later empirical work considering the formation of autonomous spaces as one way in which people try to subordinate molar social aggregates to their immanent (individual and collective) desires.

\section{Autonomy and praxis}

Intentional communities - defined as people with some common ideological commitment who choose to live and often also work together (Sargisson 2000, p. 29) have often been studied as utopian experiments or in the context of the utopian studies canon (for some excellent examples see Webber 1959; Kanter 1972; Rigby 1974; Abrams and McCulloch 1976; Veysey 1978; Pepper 1991; Sargisson 2000; Sargisson and Sargent 2004; Horrox 2009). In this project I have expanded the field of study 
somewhat to include not only those spaces where people live together, although these do constitute the majority of the case studies considered later. Rather, intentional communities can be seen as one example of a type of community within a broader movement for autonomy including, but not limited to, social centres, eco-villages, housing co-operatives, intentional communities, travelling communities, some protest groups and workers' co-operatives (Moylan 1986, p. 28; Bey 1993; Pickerill and Chatterton 2006, pp. 731-732). This list should not be seen as exhaustive, and indeed the field is potentially limitless since definition should be undertaken in terms of function rather than form, and movements for autonomy 'do not subscribe to the belief that there is one over-riding truth or one true form of autonomy' (Katsiaficas 2006, p. 8). My benchmark for case selection was that communities' aims spoke to the following criteria, adapted from Katsiaficas' framework for autonomy: independence from hierarchically organized political parties, trade unions, traditional conceptions of politics and corporations; collectivism; participative forms of decision-making, particularly consensus; oppositional and resistant orientations; belief in diversity and continuing differentiation; belief in self-management; orientation towards the transformation of everyday life (Katsiaficas 2006, pp. 7-8; see also Moylan 1986, pp. 209-210). Further, autonomy from the state is not necessarily comprehensive or total but is rather partial and based on intent, desire or purpose along a variety of parameters (Chatterton and Hodkinson 2007). This focus on desire, intent or purpose within literatures and practices of autonomy is important. Whilst intent is certainly not essential to utopianism (Garforth 2009), making it possible to 'read utopia' through a wide range of practices and affects (Bloch 1986; Anderson 2006; Kraftl 2007, 2008), autonomy is both intentional and refers to self-determined and continually differentiating desire rather than fixed social production:

Calling forth autonomy does not simply lead to concrete solutions to change the world. Nor is the term a panacea. To offer it as such would sustain the problems of blueprints which plague the contemporary world. However, autonomous geographies are part of a vocabulary of urgency, hope and inspiration, a 
call to action that we can dismantle wage labour, the oil economy, or representative democracy, and that thousands of capable and workable microexamples exist (Pickerill and Chatterton 2006, p. 731).

If utopianism is also an expression of desire as propulsive desire, then there is some equivalence of the concepts. Yet utopias include imaginary and aspirational actualizations of desire, and in principle include any desires, including reactive or conservative desires, whereas autonomy is usually associated with social and material actualizations, and usually only those that relate to anarchistic forms of organization that reject rupture between means and ends (Bey 1985; Anon 1999). In practice this often means that autonomous communities, whilst often founded upon constitutional aims and principles, leave much open to both chance and deliberation, through processes such as consensus decisionmaking.

Practices - embodied formations of utopian desire - are of fundamental importance for a number of reasons. First, excesses and differences that might arise in practice inform the ongiong process of critiquing and transgressing transcendental epistemologies (Sargisson 2000; McManus 2005), preventing them from becoming stagnant or totalizing. Second, practice is an important aspect of social change, since it allows the formation of structural bonds and communities that prefigure an emancipated society (Buber [1949] 1996, 1951; Ward 1973). Third, materialized autonomous utopias can act as a practical means to satisfy immediate needs and desires (Bey 1985; Anon 1999). Finally, it should be noted that the utopian tradition has often been concerned with the relationship between epistemological critique and social change (Sargisson 1996, p. 52, and 2000, p. 129; Amster 2009, p. 292). Alienation occurs in psychological, social and ecological spheres (Karatzogianni and Robinson 2010, p. 36), as must resistance through the active articulation of desire. For these reasons, this article, which remains an exercise in normative theory, also involves attention to practice, exploring these different functions of autonomous groups thematically with relation to the spatial focus of the article. The particular communities studied and the methods used to study them will be considered in more detail later. At this point I would like to 
turn to a consideration of the particular aspect of social-production that this article sets out to critique using a theory and praxis of autonomous utopianism - the spatial ordering of everyday life in industrial society and the utopian urbanism that both critiques yet, I argue, paradoxically reinforces alienated social forms.

\section{Autonomous utopianism and spatial theory}

The assumption of the approach outlined above is that possibility should not be limited to the present frame; in this case the present frame is taken to be the organization of space into distinct urban units of cities which are separated by rural areas. In this section, I am not concerned with formulating precise definitions of 'urban' and 'rural', or 'city' and 'country' but rather with mapping the ways in which a conceptual boundary is maintained between these spatial concepts by much existing utopian theory and critiquing this conceptual boundary by considering other (utopian) possibilities (both theoretical and practiced). Roughly, however, urban areas are taken to be large, high-density population areas (Davis [1965] 1996, p. 22) which are functionally tied to industrial production or mass economic activities. Rural areas are defined by land-use concentrated on food and primary goods production, with low population density and small settlements such as hamlets and villages. Whilst recognizing (indeed contending) that this definition is problematic, since precise functional distinction is somewhat arbitrary (Davis [1965] 1996, p. 23), varies quantitatively and qualitatively between nations and regions (Robinson 2006) and temporally in the transition to a post-Fordist economy (Amin and Malmberg 1994, p. 227) my main point of concern is that a large section of spatial theory takes definition to be unproblematic, and further assumes that not only should the present frame be limited to urban spatial organization but so should utopian imaginings themselves. My contention is that this placing-of-limits upon the utopian imagination reproduces the alienation of space in capitalist macro-geographies, and that a desire-affirmative utopianism should reside not in any place in particular, but rather in the construction of autonomous spaces whether these be urban or rural. 
In exploring the relationship between critical utopianism and the city, this article will begin with a critical assessment of various theories which, despite their differences, reproduce the image of the city as the privileged site of utopian agency. I shall argue that such authors bend the stick too far in suggesting an essential relationship between critical transformation and the city. Rather, spatial utopianism - as the active articulation of desire - is an attribute of no site in particular, but rather, of autonomous ways of relating to particular sites so as to turn aside their scalar inscriptions and the segmentary division of space (Deleuze and Guattari 1988, p. 230). This conclusion will be maintained by bringing my critique of utopian urbanism into contact with the actual discourses of members of autonomous communities, both rural and urban. It will be suggested that both urban and rural autonomous communities can be seen to embody forms of community which transgress the urban-rural divide and point towards different, nonsegmented ways of relating intensely and humanly to space.

\section{Utopian urbanism}

To begin, however, it is necessary to explore the theories I take to constitute the field of utopian urbanism. Not all the theorists under discussion self-define as theorists of utopianism, but defining utopianism in broad functional terms as 'the expression of aspirations for a desired way of being, or a future state of society, by an individual or group' (Levitas 1990, p. 189), or more simply as 'social dreaming' (Sargent 1994, p. 3) they can consistently be subsumed under this category. In my view, a broad range of theorists over-emphasize the city as a site of utopian action, failing to recognize the potential contained in rural utopias and underestimating the need for urban utopias to critically interrogate the urban-rural divide. Hence, such theories fall into the trap of a teleological modernism which portrays the privileged sites of action in terms of progressive unfolding, rather than as constructions arising from disparate desires and subjectivities.

For Castells, traditional urban sociology lacked an identifiable object of study. From his Althussurian Marxist epistemology, late capitalism is such an integrated totality that the city is no longer 
a relevant unit, because the urban is everywhere (Castells [1972] 2002). Thus the object of urban sociology must be redefined as 'collective consumption' (Castells [1978] 2002, p. 107), which creates the conditions for class alliances and popular struggles against the ruling class (Castells [1978] 2002, pp. 112 125). Groups engaged in such struggle are never autonomous from capitalist totality, nor are their 'direct effects' as important as their effects upon public opinion and policy 'at a general level' (Castells 1978, p. 2). He therefore argues against urban movements as local and partial, insisting on their transcendence through the rejection of capitalism. However, with capitalism located mainly in social relations identified by Castells with the urban, this implicitly retains the privileging of the city as a nodal site, even while insisting on the transcendence of purely urban concerns within urban social movements. For Castells, then, the city does not really exist within space - it is an ideological expression of social relations (yet what is expresses is nodal and privileged), rendering autonomous, local and specific ways of relating within and to space impossible.

Saskia Sassen $(2006$, pp. 281, 305) does not go as far as Castells in privileging the city, emphasizing the possibility of global, transversal citizenships. Despite this scalar multiplicity Sassen continues to identify the city, particularly the global city, as the main site of transformations (Sassen 2006, p. 80). It is the global city as a privileged site of multiplicity which provides the 'strategic terrain' for 'the production of "presence" of those without power and a politics that claims rights to the city" (Sassen 2006, p. 90), thus allowing for 'a partly denationalized urban space that enables a partial reinvention of citizenship as a practice and as project' (Sassen 2006, p. 281). While the agents of transformation in such a space are often the excluded and marginalized (Sassen 2005, p. 84, 2006, p. 281), they nevertheless engage in transformative practices mainly through and in the special site of the global city, articulating 'rights to the city' which relate specially to this privileged space.

Engin Isin $(1997,2000,2007)$ offers a similar account of the effects of shifting territorial formations upon the institution of citizenship and agents of transformation. His work depends on counterposing the city as a utopian site to the state as a hierarchical space. 'The city' is seen to be an 
alternative (rather than supplementary) type of body politic to the state and thus a backdrop for an examination of 'citizenship beyond the state' (Isin 2007, p. 211). This approach sees the challenge to statist hierarchy not only in processes above and beyond the state, but also at the lower level of nested spaces such as cities (Isin 2007, p. 211). Yet the city is not simply one among many nested spaces. Isin argues that the city differs from all other bodies politic, insofar as it exists as both actual (urbs) and virtual (civitas) spaces, as a set of things and bodies but also as a symbolic entity beyond these. All other bodies, including states, nations and so on are seen 'not as actual but only as virtual spaces that exist in ephemeral, fluid, impermanent and transient states. These virtual bodies are assemblages that are kept together by practices organized and grounded in the city' (Isin 2007, p. 212). The virtuality of other spaces does not mean that they are unreal, or do not have effects, but that 'they do not exist in themselves but only in representations and effects' (Isin 2007, p. 212). Like Sassen, Isin argues that 'the city' is the backdrop for social struggle, and constitutes 'a difference machine insofar as that space which is constituted by the dialogical encounter of groups formed and generated immanently' (Isin 2007, p. 223). The concreteness of the city thus defines it as an emancipatory site against the reductions of statist reasoning

Murray Bookchin $(1974,1992)$ offers a more explicitly utopian vision of the city as a site for an 'eco-anarchist' conception of citizenship, and attempts to address problems of unsustainibility in the contemporary 'megapolis', constructing a vision of the de-urbanized city. Nevertheless, he broadly reproduces the segmentary division of space. He extolls the virtues of the Athenian polis at great length, where 'life was to be spent in the agora ... in which citizens gathered daily to conduct their affairs, gossip, argue politics, and sell their wares' (Bookchin 1974, p. 97) and argues for a future spatial organization of small-scale confederated municipalities based on the Athenian model, where the means of production is brought under citizen control and civic institutions are restructured to provide a public sphere for direct democracy (Bookchin 1992, p. xxi). Despite these proposals, utopia is viewed in terms of a particular content - a deferred and specified end - rather than in terms of an immanent critical and desiring function (Bookchin 1992, p. xxi). Although not seeking (like Sassen and Isin) to reintegrate the 
reclamation of citizenship and transformative agency into existing structures, Bookchin still seeks to incorporate such difference at the 'scalar' level of a confederation of municipalities.

Pinder's work on utopian urbanism repeats a similar emphasis on the city. Pinder rightly expresses concern at 'the general retreat from utopian urbanism in recent years' (Pinder 2002, p. 229; see also Baeten 2002), a decline he sees arising from a misguided rejection of utopianism in the aftermath of the collapse of Stalinism. Against this rejection, he posits a need for critical utopianism. Scepticism about utopianism, although justified in many respects, has ethical effects - in particular, a decline in thinking creatively about social justice and progressive politics in favour of selective regeneration, which insulates those with money and power from urban social problems (Pinder 2002, p. 231; see also Harvey 1996). Pinder (2002, p. 238) argues in favour of rethinking the definitions of utopian urbanism, and foregoing traditional notions of 'an ideal state or spatial form for a perfect future' in favour of a process-oriented vision of utopian urbanism as 'the desire for a better way of being and living'. Utopian urbanism therefore becomes 'a process of exploring desire itself', and an emphasis is placed on the disruptive function of utopianism (Pinder 2002, p. 238). This resonates very closely with my own approach to utopianism, although I am wary of Pinder's restriction of the utopian method to urbanism, which strikes me as an unnecessary limitation of a frame which can be applied more broadly.

\section{Critique of utopian urbanism from the standpoint of autonomous theory}

The importance of utopian urbanism should not be dismissed. These theorists view utopian articulations sites of resistance and critique, which simultaneously offer possibilities for a better future. Such possibilities emerge from the denaturalizing of the relationship between territory and citizenship, or political agency and the state, and the strategic intersection of particular urban sites with concentrations of power. While embracing these social conceptions of utopian transformation, and approaches to utopianism as arising in an excess in local spaces over their statist or scalar inscriptions, this article suggests there is a need to move beyond the exclusive privileging of the city as the site of such 
contestation, recognizing instead that autonomization or dis-alienation of space can happen in both urban and rural spaces, and that contestation of the urban-rural dichotomy is an aspect of such autonomization. The urban-rural divide is in large part a product of dominant hierarchical arrangements, reinforced by neoliberal globalization and the current separation between marginalized subsistence or peripheral zones and concentrations of resources in global cities (Gottman 1980). In this context, the claim to 'rights to the city' is transgressive only up to a point: it creates space for minorities to make spatial claims, but these claims are of a reformist kind, retaining a relationship of demand to a centre (the city or state) which preserves scalar divisions on a deeper level.

\section{Inability to produce epistemological 'otherness'}

In taking the city to be the privileged ontological site of political critique and transformation the above thinkers effectively reproduce a teleological form of reasoning which attributes progressive force to aspects of current social processes. As a result, they articulate the virtue of the city as if it were a natural and insurmountable aspect of History as a predetermined process. I would argue, in contrast, that the utopian function of theorizing emerges through creating critical distance from existing trends and dominant social forces. Historically, cities have sometimes been peripheral sites in relation to rural concentrations of power (The Invisible Committee 2009). A full account of socially situated belonging must take account of indigenous forms of spatial belonging such as extended kinship structures, local polities, 'clans' or 'tribes' and their habitations (Clastres 1977), villages, networks of situated relations, and those associated with forms of work, such as guilds (Black 1997, pp. 104-105), as well as the type of emergent autonomous spaces that will be considered in this article. It is thus misleading to associate social belonging and transformation mainly with the city. It is in contesting the dominant constructions of political necessity that the possibility of utopian otherness emerges (Bauman 1976, p. 13).

\section{The city reproduces alienated relationships}


Another difficulty is that, in a concrete sense, cities are not autonomous polities, but rather, depend on agrarian practices occurring in the 'rural' space. The separation between town and country, and therefore of spheres of life, assumed by the very concept of a 'city' always-already implies the separation and striation of space, meaning that the city is inevitably urban and embedded within state structures (Deleuze and Guattari 1988, p. 501). Deleuze and Guattari (1988, p. 531) speak of how the city creates a divide from cultivation and operates to organize and allocate agricultural space, by 'superposing farmers and their striated space ... upon the cultivators operating in a still smooth space'. For Virilio, the city is akin to a 'communal fortress' (Virilio 1986, p. 10) imposed upon free social flows by the capitalist class in order to maintain a permanent 'state of siege' (Virilio 1986, p. 12). The opposition is not so much one of city to country 'as that of stasis to speed' (Virilio 1986, p. 5), with 'the very givens of capitalism, the inactivity of its wealth' (Virilio 1986, p. 12) creating the conditions for the emergence of the city-fortress and permanent state of war through the building of frontiers and boundaries designed to regulate speed, circulation and intensity of autonomous flows. Thus the city (as a concept and a practice) might be interpreted in a sense as anti-utopian, insofar as utopia - in its most critical function - is an open process of exploring desire, whereas the city, through the forms of capitalist mediation that it reproduces, is the embodiment of psychological, social and ecological alienation.

As a result, an emphasis on the spatial form of the city excludes agrarian practices and alienates subjects from some of the practices that are required to sustain their lives, setting limits on the radicality of spatial rethinking and utopianism. As Stirner argues, failing to trouble oneself with the provision of the necessities of one's life, such as food, leaves one in the situation of depending on what others choose to put aside for such purposes (Stirner [1844] 1993, pp. 275-276). Although Stirner does not explicitly address spatial arrangements, taken to its logical conclusion, his argument might imply that all should be involved in the growing of food, which undermines the vast distances between areas of inner-cities and the countryside. In concrete terms, practices such as urban farming and overcoming the urban-rural division have been a central part both of historical utopias (Kropotkin [1899] 1913) and contemporary environmental movements (Hopkins 2008). Such practices fundamentally de-urbanize the city, taking 
contestation to a different level. De-urbanization - when it does not rely on blueprints or aim for utopian substitution with pre-existent spatial forms, such as the rural idyll - is an active expression and exploration of desire, because it involves moving away from fixed, alienated spatial forms through direct connections and the construction of (material and relational) autonomy and immanence; in other words, subordinating social production to desiring production.

One could go further, associating urban life with alienated life and in particular with alienation from ecological networks. The most visible effect of this delinking from the ecosystem is that urban life tends to be ecologically destructive, as for instance in the reliance on transport across distances between zoned urban areas in daily life. In contemporary cities this would include the use of private transportation, which generates vast amounts of carbon dioxide (Garner 2000, p. 21) - exemplifying a more general problem that cities have historically been built to serve the purposes of trade, industry, and the market rather than people and their environment (Harvey 2000, p. 217). Although these examples concentrate on the contemporary city, it is arguable that similar instances of the mass movement of resources from one area to another are a fundamental conceptual limitation that would occur in both ancient and future cities, which raises questions over whether cities can operate as effective spaces for a sustainable utopian practice in the long-run. The contemporary city is also socially unsustainable due to increasingly dense populations leading to rising house prices, aggression and crime due to competition over space and resources as well as drastic inequality symbolizing the domination of global capital over poverty-stricken local areas (Chatterton and Hodkinson 2007, pp. 202-204).

\section{The city subordinates active desire to social production}

A further problem is the elision of the particular, and subsumption of local forms of belonging into capitalist macro-geographies. Urban spaces frequently embody alienation in terms of the privileging of 'modern' or 'cosmopolitan' forms of impersonal belonging over immediate, personalized and intense forms of interaction and community. The agora, the marketplace, the 'non-places' (Augé, [1995] 2008) of 
transit hubs and Central Business Districts (CBD's) are all instances of impersonal belonging in which personal connections and attributes are elided beneath abstractions. The non-belonging of non-place is perfectly suited to the transnational elite, whose ability to travel between local sites gives them poweradvantages over those who remain local (Hannerz 1990). The danger of utopian urbanism is thus that, in its uncompromising cosmopolitanism and modernism, it elides the importance of the local and of intense, immanent relationships to space and production.

Such impersonal relations are a target of critique, and radical theorists have moved towards constructing desire-affirmative alternatives in the form of dis-alienated utopias of process. Classical and evolutionary anarchists talk of the distinction between the 'political principle', referring to hierarchy and the state, and the 'social principle', which is 'a living togetherness' constantly renewing itself through 'the immediacy of relationships' (Buber [1949] 1996, p. 135). The social principle must be differentiated from sovereign and abstracted territory and the associated ideas of universalism and unification, since it exists through non-abstracted face-to-face relationships and the immediate negotiation of difference at the level of the desiring-producing community (Buber 1951, p. 7; see also Kropotkin [1896] 1970, passim; Landauer [1911] 1978 p. 43; Buber [1949] 1996, pp. 80, passim). Similarly, the Situationists attacked modern urbanism as a 'technique of separation' and the representation of the functionalist categories of the city 'as dogma or absolute truth' (Andreotti 1996, p. 13) and saw the city as the site in which the capitalist division of labour and the fragmentation of life intensified, and thus could be effectively challenged (Vaneigem [1967] 2006, p. 188). The situationist response was to formulate modes of resistance, such as 'unitary urbanism', 'détournement' and the 'dérive' (Vaneigem [1967] 2006, pp. 185-189, 234; Unsigned 1959; Tester 1994; Debord 2002, p. 99) that are engaged in presently rather than through deferred practices of revolution or practices of representation, rooted in a subjective ontological basis of doing, rather than being, and the maintenance of constant criticism rather than fixed knowledge (Tester 1994, p. 5). This informed a critical utopian practice of resistance that resided in the simultaneity of resistance and creation, of theory and practice, and the creation of unalienated experience within and against the alienating spactacle of the city, through social disruption, self-expression and play (Andreotti 
1996, p. 15). Whilst the situationists nevertheless concentrated on the city as the site for utopian contestation (and the classical anarchists conversely often privileged rural settings), their approaches both involve the construction of immanence and autonomy that assumes a moving-beyond or disruption of fixed, pre-existent spatial forms.

Hence, a critique of alienation cannot stop at the boundaries of the city. Overcoming the separation of town and country is a recurring theme in radical thought. Marx and Engels talk of the 'gradual abolition of the distinction between town and country' (Marx and Engels [1846] 1998, p. 19), and Kropotkin also spoke of removing the distinction between town and country through a 'synthesis of human activities' (Kropotkin [1899] 1913, p. xi). Even Howard, the archetypal utopian urbanist, spoke of integrating 'all the advantages of the most energetic and active town life, with all the beauty and delight of the country' (Howard [1902] 1996, p. 347). One might add however to these theorists, who sometimes posit universalist solutions, that to be a truly critical-utopian approach to social change deurbanization should inherently challenge totalizing vanguardist models of utopia-as-blueprint by relying on immanent processes of critique and differentiation within small groups directly connected as microsocial assemblages. A spatial strategy of proliferation rather than scaling-up of alternatives removes the separation or mediation of spheres of life and activity that occur through orientation to a deferred and transcendental utopia: 'the priority of local action is an attempt to unify everyday life and fragment the mass. This level of consciousness is a result of rejecting the laws of mass behaviour based on Leninism and TV ideology' (The Red Sunshine Gang [c. 1970] 1999, p. 8).

Against urbanism as privileged space, autonomous spaces are sought on the margins. Lefebvre, who influenced the situationists, conceptualizes an 'outside' to capitalist and state space when he draws the distinction between 'dominated (and dominant)' and 'appropriated' space (Lefebvre 1991, p. 167). The former is 'a space transformed - and mediated - by technology, by practice' and 'its origins coincide with the roots of political power itself (Lefebvre 1991, p. 164). Lefebvre emphasizes the importance of desire, and the education of desire through theory and practice, in a form of resistance that occurs 
through the (re-)appropriation of space from dominating forces (Lefebvre 1991, p. 166). In Deleuze and Guattari's (1988, pp. 408-411, 524, 530) works, similar processes are conceived in terms of the smoothing of space. One might similarly refer to Bey's $(1985,1993)$ autonomous zones, Colin Ward's (2002) histories of squatted sites, McKay's (1996, pp. 35-38) idea of an 'Albion Free State' running against the dominant view of England, and autonomous geographies which recreate social ties through practices of 'horizontality' and non-hierarchical relationships (Hodkinson and Chatterton 2006; Pickerill and Chatterton 2006). I shall argue that these approaches to autonomy provide a more useful way of engaging with actual practices of prefigurative utopianism than a theoretical emphasis on the urban as a privileged site. In contrast to the impersonality of the city - even Bookchin's 'de-urbanised' city of the agora - the communities discussed below are assertively local, even while refusing the closure of perspective connoted by this term. In a sense, they fuse cosmopolitanism (a global scalar disposition) with locality, at the expense of the segmentary intermediary scales such as nation and city. The local node relates to the wider world through open-ended solidarities and especially through the network form, not through scalar insertions (Juris 2008; Robinson and Karatzogianni 2010).

\section{Beyond the city: autonomous and utopian practices}

In exploring the limits of utopian urbanism and the possibility of moving beyond them, I now turn to immanent and prefigurative practices within autonomous spaces. Visits to ten communities involving participant observation and twenty-two interviews with members were undertaken during the summer of 2007 as part of a wider research project (Firth 2011). The current article builds upon the methodology used in the book, which focused on some key utopian concepts of political theory, by bringing it into dialogue with human geography and spatial theory in a critique of urban utopianism. The remainder of this article attempts to take preliminary steps towards deconstructing utopian urbanism by bringing the voices of practitioners involved in creating autonomous spaces into dialogue with some of the academic theory discussed above. Whilst the approach of this article suggests a post-representative epistemology 
and ethics, some degree of representation is unavoidable in written work. Nonetheless taking seriously the imaginings and articulations of practitioners involved in the production of autonomous spaces who would not normally be considered theorists signifies a move towards full presence and can have the critically transgressive effect of disrupting fixed ideas. Of the spaces visited for this project, three could be classed as rural, six as inner-city, and one as suburban. Communities were selected according to criteria of similar articulations of desire or intent, therefore shifting the focus towards autonomy as a positive exemplificaltion of producing and re-producing anti-hierarchical relational practices rather focusing on intentional communities as physical or ideological 'withdrawal' from mainstream society (Meijering, Huigen and van Hoven 2007). Autonomy is therefore operationalized through analysis of aims and principles drawn from constitutions and founding documents and compared to Katsiaficas' framework of autonomy, discussed above. There is evidence that in practice geographic situation and specific social, political and material contexts had effects upon the limits and possibilities of practice. However, these limits are partially or functionally overcome by means of transgression of the urbanrural divide and the production of dis-alienated relationships.

In particular, there are three ways in which the theoretical privilege of the urban as a site for transformation is overcome in autonomous spaces. I concentrate on the utopian functions of autonomous spaces identified in the methodological section above. First I explore ways in which their ideas and practices critique and transgress epistemological assumptions of much spatial theory such as the urban-rural separation and the privileging of the urban as a site of political transformation. Communities can be rural as well as urban and there is little reason to assume that rural sites are less appropriate for utopianism than urban sites, and in some respects, the rural setting creates possibilities (for relative invisibility, reduced pace, direct community and ecological living) which can suit utopianism well. Second I consider some practical ways in which emergent free spaces point to new ways of living in space. Urban autonomous spaces often subvert the alienated division of urban space through creative practices such as urban farming. Such practices directly incarnate aspects of the rural, such as primary goods production, within the urban. Third I consider how autonomous communities potentially 
constitute dis-alienation through the construction of immanent social bonds and the articulation of active desire, for example through practices such as co-housing and collective childcare which involve an attempt to overcome the alienation of city living. The conclusion considers the relationship between epistemological critique and social change suggested by these functions, as well as some limitations of both the research itself and the practices of the researched communities.

\section{Autonomous spaces and the utopian function of epistemological criticality: transgressing the urban-rural divide}

Both rural and urban locations had advantages and disadvantages for participants, suggesting the possibilities of utopian urbanism but also its limits. Autonomous communities often seek the best of both worlds between urban and rural and also to move beyond these categories by affirming alternative desires. The preference for urban sites arises largely from their operation as cosmopolitan centres of mobility and difference. A major advantage of urban sites identified by interviewees is that an urban setting facilitates contact with people from diverse backgrounds, taking advantage of the cosmopolitanism of the city. For instance, interviewee A-- of Kebele - an autonomous social centre in Bristol argues that, in an urban 'melting pot' like Bristol, 'you get different views and trying to work across those different views is just as important as trying to do what you are doing'. This contact with difference is taken to 'widen your own opinion or your views and be able to see and understand where other people have come from'.

On a practical level, city locations lend themselves to visibility and political activity, perceived to facilitate wider transformation. F-- of Coventry Peace House, an urban housing co-op, refers to initiatives such as monthly stalls on peace issues and a programme for inner-city children teaching about development and peace-building. A-- of Kebele also identifies visibility as central to the urban site, suggesting that one can 'lead by example' in a city such as Bristol. On the other side of the urban-rural divide, P-- of Laurieston Hall, a rural intentional community, bemoans the 'monochrome' class and ethnic character of rural communities in contrast to the multiplicity of cities, and identifies occasional 
trips to cities as occasions of excitement due to the diversity of people: 'I love seeing different colours and different skins and different accents... and it's just a gas, just walking around there, and going to all the different restaurants with all the different foods and things'. Contact with different cultures within the urban space yet often outwith the autonomous space can thus initiate a kind of polyphonic dialogue (Bakhtin ([1929] 1984) that can prevent ideas from becoming stagnant, or fixed, static utopias at an epistemological level. Whilst this points to possibilities for utopian functions within the urban that might partially confirm those theories which view the city as a more radical site of transformation, there are further points that merit consideration.

The view of the city as more intensely political was not endemic, and there was also a view that the city is such a busy place that it can detract energy from community life and political activities. A-- of Mornington Grove, a housing co-operative in London argues that a rural community would find it easier, because London's quality of being 'very very busy', combined with needs to balance the community with personal and working lives, render it difficult to sustain a community. This also suggests some difficulties with constructing strong social bonds within the alienated environment of the city. E-- of Laurieston Hall speaks of being unable to be involved in political activities such as political parties and demonstrations because of childcare and community commitments, and therefore finds the slow pace and immediacy of a rural community more appropriate to make a difference through direct changes in ways of living.

On the other hand, rural sites have some advantages which confound utopian privileging of urban sites. Rural settings are often more appropriate for ecological communities due to the greater possibilities for self-sufficiency. E-- of Laurieston Hall saw the rural setting as providing potential advantages in terms of self-sufficiency and the possibility of ecological practices:

Coming here made me think that I would have more opportunity to become more involved in green politics at a root level... living here means I can contribute more to that because we've got a very 
involved recycling system, because we're into buying solar panels for the roof, and we've got hydro, and we've got pigs so all our waste goes to the pigs, and things like that I just really love and appreciate so wanting to be part of that is one of the main aims that I see for living here (E--, Laurieston Hall, 2007).

This respondent addresses issues of moral intent and political agency. The interviewee explicitly considers, and dismisses, traditional political activities associated with vanguardism and mediation of state and party. She appears to reject, or downgrade the importance of, these activities in favour of 'green politics at a root level'. This allows actualization of a particular vision, involving the proliferation of small-scale utopian experiments rather than the scaling-up of territory and politics. Utopian transformation in this case is thus associated with desiring-production rather than social production, and is desire affirmative since it involves direct connections and a horizontal approach to both organization and transformation. The interviewee perceives this immediacy to be specifically enabled by the rural nature of the setting, suggesting in this case an intersection of the autonomous function of spatial utopianism and the immediacy of propulsive utopia with the rural rather than the urban. Yet it is not simply a case of privileging the rural at the expense of the urban in order to refute those theories which view the city as a more radical site of transformation, but rather of considering the ways in which practices across sites can transgress the divide itself.

In many regards, the rural is more appropriate as a site for those varieties of utopian communities in which immediacy of interaction and autonomy are major objectives. The local level in rural communities can express itself as a primary locus of belonging, in contrast to scalar thought. For instance, P-- of Laurieston Hall describes himself as a 'citizen' of Laurieston Hall rather than the nationstate: 
If I was to ask what supports me, and what expresses my values, and what places its feet on the earth in a way that I approve of, it's this one, so it's not an abstract connection, it's a real connection. Whereas with British citizenship, it's just a pure matter of chance and an abstraction, it has absolutely no meaning whatsoever (P-- of Laurieston Hall, 2007).

Within the interview, the same respondent likens the experience of Laurieston Hall to the film Passport to Pimlico in which a small area secedes from the UK, arguing that despite its partial reliance on imports, the community fosters a feeling that it 'has declared independence from the rest of the world'. This clearly shows that the critique of scale associated by utopian urbanists with reclamation of urban spaces is equally apposite in the reclamation of rural spaces, and not at all exclusive to the former. These small spaces express and actualize a different logic to hierarchical, territorial, models of space, and thus are to a certain extent 'outside'. The utopian function to some extent requires an enclave, or a degree of isolation from the outside, in order to practice these unmediated relationships, to learn to desire something 'other' and to affirm such desires through direct relationship with other members and the environment.

Similarly, M-- of the Findhorn Foundation discusses the loss of the immediacy of face-to-face relationships as a problem with capitalist modernity. This is not, however, articulated as a rural counterpole, but as a view of autonomous community as recomposition:

I think if we look at the situation in the Western world, community is definitely something that has been lost, and we have to re-engage with community at a different level of awareness. This isn't going to be the little family that all grew up on the land in the same vicinity. That's long gone, we've all migrated and mobilized everywhere, so rebuilding community and not just the people part of community but also the landscape and all of the life of the place. And although we are in a fairly rural setting, I think it also applies to urban areas that have neighbourhoods. It's just as much a neighbourhood thing as a rural community thing of really working to what brings people together. 
And so much of the design of things, you know high-rises and things, just doesn't build community, you can actually build community by design, by landscape (M--, Findhorn Foundation, 2007).

Overall, therefore, one finds in the views of community participants a sense of the nuances of advantages and disadvantages of different kinds of spaces for the actualization of utopian desires, confounding the simplistic association of such processes with the urban as an exclusive locus. The idea that once can build community by design and landscape also suggests direct environmental connections, and the overcoming of ecological alienation. Above all there seems to be an emphasis on moving beyond set spatial formations such as urban-rural through a concentration on the recomposition of social bonds. Whilst the utopian 'alternative' to an urban-rural separation is not always clear, since communities are small-scale and do not rely on spatial plans or blueprints (except arguably in the case of Springhill, which was built from scratch by the founders), there is a clear critical and reflexive attitude towards uses of space and the kinds of relations that these might actualize. Whilst there is clear intent here, the intent is not closed or future-oriented but rather relies on practice as a realm of transgressive epistemological critique of dominant spatial formations. There are however limits to the extent to which these communities transgress dominant spatial formations, and critique might be taken elsewhere and further, in directions that will be signalled in the conclusion.

\section{Utopian spaces as immanent and prefigurative spatialities: actualizing alternative environmental and social relations}

What is more, when communities form in urban sites, they frequently move towards deconstructing the urban-rural binary by incorporating rural practices into the urban space. For example, permaculture is a popular activity in several urban autonomous spaces, such as Peace House in Coventry, Corani in Leicester, Springhill in Stroud and The Sumac Centre in Nottingham, and was in the process of being instituted at Kebele in Bristol during the time research was underway. Permaculture can be defined as 'a design system for the creation of sustainable human settlements' (Hopkins 2008, p. 136) that successfully 
assembles the various components of human settlements and communities, including social, economic, cultural and technical in stable and productive ways (Hopkins 2008, pp. 136-137). The practice of permaculture is a central principle of a broader Transition Towns movement, which provides communities with guidelines for processes to help them move towards 'rebuilding local agriculture and food production, localizing energy production, rethinking healthcare, rediscovering local building materials in the context of zero energy building, rethinking how we manage waste' (Hopkins 2008, p. 15). In practical terms for the communities that I visited, this usually meant dedicating parts of the space to vegetable gardens run according to sustainable principles and using environmentally friendly energy sources such as solar panels and wind turbines:

We have the fledgling permaculture sub-group, people who are looking to do some permaculture design on the backyard at the back of the building, with a further view to move onto like solar-power, heat and water, things like that, added on with wood-burners and things like that (T--, Kebele, 2007).

This transgressive 'ruralization' of urban communities correlates with a tendency to recompose communities as local sites, in resistance against the impersonality of urban space. While urbanism is typified by scalar and capitalistic uses of space, communities sought to use space in alternative ways more akin to those of village communities. M-- of Springhill, a co-housing community in Stroud, recounted that the community have common facilities such as a common house, kitchen, dining room, work-space and gaming facilities. The co-housing community put on meals for the community three times a week, and seek to pool labour and share facilities to reduce resource consumption, including carbon emissions, and raise the standard of living. Such practices can be efficient, environmentally friendly, money-saving and also build community. While such measures are taken to encourage community, further conventions are undertaken that exclude the less conducive aspects of urban life: 'Cars are kept to one side of the site purposefully, and the site is largely pedestrian, which is great for 
kids and the dogs'. Hence, the site retains its human scale and temporality through a selective exclusion of aspects of the pace and speed of urban life. Such practices transgress the too often taken-for-granted urban/rural divide by bringing agriculture into the city, overcoming alienation by constructing direct social and ecological connections in the process of producing primary goods. They also politicize activities that would usually be relegated to the 'private' sphere, and not associated with the 'public' activities of politics, from energy production down to the realities of dealing with waste (Sargisson 2001).

\section{Autonomous spaces as expressions of active desire}

Urban spaces tend to rely on atomized, impersonal relations among people. Part of the function of intentional communities is to restore a denser form of social life in which the closeness of a rural community is reproduced. M-- of Springhill argues that:

In Denmark, where co-housing is very popular, the message that you get there is that co-housing is a family paradise, certainly I think that the families here really enjoy it, because there are lots of people who know the children quite well and so when it comes to it if you have to get involved with a dispute or something with the children, you know the parenting styles of their parents so, there is lots of childcare ... a good member of Springhill would be a number of things, it would be someone who had time to talk, had time to listen, to be in meetings, who was prepared to muck in and help, prepared to share; cars, time, materials, machinery, you know whatever. Who would be prepared to help someone who was going through a bad time, to be a listener and support. (M--, Springhill, 2007)

The model here would seem to be the extended kinship system, usually consigned to peripheral rural regions in the world-system as a mode of social reproduction, as opposed to the nuclear family of urban production zones. In contrast to standard urban space, communal spaces therefore have several functions. They facilitate the breaking down of boundaries and the immediacy of face-to-face 
relationships, fostering a sense of community and belonging. While enabling members and guests to socialize and form connections, they also often have practical or educative functions, such as those of working gardens, classrooms and workshops. Privatized functions such as childcare and cooking are often collectivized. In the case of Peace House, P-- recounts that a cycle repair workshop and resale project makes a practical environmental contribution, while a night shelter and education project make a practical peace-building contribution. C-- of Liverpool Social Centre describes the space as an attempt to 'create a political hub' oriented to non-hierarchical community groups, offering facilities such as photocopying, printing and computers for free. 'So we will be helping people with campaigns, as opposed to trying to run campaigns, we'll just help them and provide stuff.

Such practical uses are complemented by an aesthetic relationship to space. T-- of Kebele, Bristol, emphasizes the use of the space for art exhibitions. 'I think of the whole of Kebele as a work of art, but we have a space in the café for particular exhibitions. And we have screen-printing on Thursdays'. This echoes a situationist view of space as aesthetic, transgressing urban models of functionality to integrate art with life. Such a tendency is implicit in many of the urban communities, which turn spaces that would otherwise be used for residential or commercial purposes into spaces for leisure, culture and community activities. Frequently such activities are run by sub-collectives, with fluid membership, where decisions are made by consensus. This is a practice of 'de-urbanization' of urban spaces, recalling the situationist logo of recovering the beach beneath the paving stones (Plant 1992, p. 104), removing the alienation produced by the realities of functional separation in social production (such as primary/secondary production, work/leisure time) and replacing them with the desiring-production of the community as a continually differentiating assemblage.

Participants are sometimes aware of the transgressive aspect of their use of urban space and the resistances their activity faces from the wider urban context. A-- of Mornington Grove Community in London describes the community as 'very peculiar ... because it is a community, but also in London'. The urban location creates challenges, which are met partly through substituting the community for the 
density of rural life: 'I love it like that and we kind of share the same values, and that's the core of this community'. However, A-- also states that 'for me at least it is really challenging to merge the both', in the sense of urban living and community. It seems, therefore, that a struggle is being waged to build a type of community in some respects inimical to the alienated, high-speed urban setting. A--'s typification of the community as 'very peculiar in a way' suggests an intuitive sense that boundaries are being transgressed in bringing such 'human-scale' community attributes into an urban site.

With ecological and immediate social forms of affinity prevalent over impersonal belonging, community participants often articulate understandings of their own belonging and relations in broader terms than those of dominant models, such as T-- of Kebele's view of herself as a 'folk citizen' of a history of (partly agrarian) counter-movements, and as an 'autonomous person' rather than a citizen:

history is written by some people with certain agendas, so my, kind of links to the past are, what I'm interested in is the social history of revolution, and how people lived, and dealt with landlords and stuff, so I'm a kind of 'folk citizen' rather than a citizen (T--, Kebele, 2007).

This idea of 'folk-citizenship' is utopian in a manner that articulates active desire as theorized above, insofar as it reconstructs identity based on a chosen rather than ascribed affilitation, and also in that it is a nomadology (Deleuze and Guattari 1988, pp. 387-467), constructing becomings and active memories rather than fixed categories. This connects with the situationist and anarchist critiques of abstraction: that territorial spatial organization alienates individuals by emphasizing a primary relation to a centralized sovereign power (Stirner [1844] 1993; Vaneigem [1967] 2006). Like T-- participants frequently expressed feelings of being able to write their own histories and shape their own life-worlds in combination with those around them, rather than being subject to an imposed structure, illustrating a tendency to subordinate social production to desiring-production in both narrative and practical ways, overcoming alienation at psychological, social and ecological levels: 'By thinking differently, one can use thought or 
language as a war-machine, by being a foreigner in one's own tongue' (Karatzogianni and Robinson 2010, p. 18).

\section{Conclusion: autonomy, utopia, and resistance}

This article builds upon the methodology and fieldwork of my book (Firth, 2011), wherein I developed the critical utopian approach and applied it in a critique of some core concepts of political theory, including territorial sovereignty, authority and rights. This article builds upon the methodology and develops some of the core themes from fieldwork by bringing them into dialogue with spatial theory and urban utopianism, which were not considered in the book. This has led to a deeper conceptualization of the relationship between utopia, autonomy and desire. In this article, I have argued that whilst autonomy and utopia are conceptually distinct, there is strong resonance and functional overlap. I argued that an approach which works at the borders or margins of autonomy and utopia is useful, insofar as it allows one to examine the intersection of desire with intent, whilst privileging active, unmediated desires and open-ended, processual non-blueprinting utopias. I also argued that an autonomous approach in utopian studies must involve attention to practice, since autonomous spaces serve many of the same propensities as critical utopian methodologies. In particular, both critical utopian theory and autonomous practices share three functions: epistemological critique, a political function of prefiguring and exemplifying nonalienated environmental and social relations and the micro-political expression of active desire and overcoming psychological alienation.

I attempted to apply this approach to critically examining one particular aspect of utopian theory; utopian urbanism, which whilst already critical is limited since its utopianism seeks transformation without the overcoming of alienation and reconstitution of active desire that is implied by an autonomous approach. The conflation of utopia with urbanism runs risks of reproducing alienation in the urban-rural separation and limiting what can be achieved in a utopian politics of space. Utopian urbanism thus contains problems of fixity which draw it back towards the pole of utopia-as-blueprint. In 
contrast, critical utopian theory, in imagining an outside to the status quo without positing a new hegemonic logic, allows us to imagine and begin to actualize an outside to existing spatial formations while normatively valorizing difference and self-activity. Critical utopian theory can be partially actualized through practices of autonomy - materialized resistance involving the opening up of free spaces where new forms of subjectivity and politics can be experimented with, lived out and negotiated. Utopia as social dreaming and autonomy as materialized resistance have a reciprocal relationship.

Hence, the concrete activities of autonomous communities actualizing autonomous desires demonstrate the necessity to move beyond the theoretical tendency to privilege urban space as the site of transformation, instead emphasizing the transgression of the urban-rural boundary and the actualization of autonomy as attributes of utopian transformation. This has implications for sites, formations and everyday practices of transformation and resistance. Practices in autonomous communities can bring to the urban space some of the locality and community density normally reserved for rural spaces, restoring a degree of 'human scale'. While seeking to draw on the inclusiveness and vibrancy of city life, they also reproduce aspects of the village and construct dis-alienated, desire-affirmative relationships through an emphasis on personal and small-group levels of interaction. Hence, even when occurring at urban sites, autonomous spaces break with teleological utopian urbanism, tending rather towards singularization and recomposition. Whilst much urban utopian theory posits new forms of resistance as rights-claiming activities oriented to the integration of difference into a higher unity of governance, situationist, anarchistic and autonomist positions view them as the emergence of 'lines of flight' (Deleuze and Guattari 1998, pp. 561-562; Robinson and Tormey 2009, p. 172) or 'exodus' (Illuminati 1996; Virno 1996) from the dominant system. This involves the re-making of social bonds through the creation of unalienated relationships involving the affirmation and harmonization, rather than recuperation, of difference.

There are however limits, both to the methods undertaken herein, as well as limits to the radical potential of practices within the communities. The research concentrates solely on relatively small 
communities within the United Kingdom, and on Western conceptions of cities and 'the urban'. The approach aims to be exploratory rather than confirmatory, as I did not wish to 'prove' that the practices under study constitute the 'best possible' cases, nor to insist that they might be accurately subsumed under any particular theoretical category. Rather my intention was to disrupt taken-for-granted categories through an exploration of alternative practices and to explore what the conditions for critical utopian forms of autonomous social relations and ways of relating to space might look like. Situatedness can be seen as a strength, insofar as it relies on an ethical prerogative to participate in local struggles and resistances rather than posit vanguardist universal prerogatives (May 1994, p. 118). Nonetheless, situatedness - both my own and that of the communities themselves - does tend to ignore important dynamics occurring elsewhere, that might be inspirational or taken further in study.

A limit within the communities studied here (frequently expressed by participants themselves) is that they tend to 'ghettoize' around fairly specific identities (such as white, middle-class, well-educated; see Hodkinson and Chatterton 2006), suggesting that often they are not entirely successful in constructing diverse and open immanent social relations, nor overcoming real poverty or scarcity through desiring-production (it is important to note that participants were reflexive on this issue and taking steps to overcome it; see Firth 2011, p. 131). It is also important to note that whilst communities did have wider connections to one another and to other radical organizations through the "network form' (Robinson and Karatzogianni 2010, p. 154; Juris 2008) through organizations such as Radical Routes, such connections were often occasional, and ideological rather than material. Thus similar research might be taken elsewhere and further, considering other ways in which the urban-rural divide might be disrupted through the construction of autonomy. One example for consideration might be urban communities in the Global South. Karatzogianni and Robinson (2010, pp. 198-199) detail where connections are formed and maintained between particular urban shanty communities and rural sites through migration patterns, which encourages mutual dependencies of subsistence whilst retaining an overall autonomy and self-determination of the alliance through forms of social and economic cooperation. Whilst such forms of autonomy often rely on necessity rather than intent, they might offer 
utopian inspiration for more politicized spatialities. Another further avenue for study might be an exploration of the potential for constructing autonomy in more conventional institutional structures, such as the mental health services, universities and schools.

I would therefore like to end this article by arguing that utopia as the active affirmation of desire should not be seen as an attribute of fixed spatialities, nor of any sites in particular, but rather inheres in the construction of autonomous social and environmental relations that actualize the active expression of desire. In some cases this can be intentional and in some cases issue from necessity, yet spatial utopias are political phenomena. They engage with the future by making the present a better place, and in so doing create a space from which further reflection on the problems of the present, ongoing critique and contingent transgressive dreaming - both within, and outwith the utopian space - can occur. Critical utopian theory rests an epistemological anarchist philosophy which emphasizes the articulation of different and changing desires. This resonates with autonomous themes of self-activity and opening up physical space for participation through direct, unalienated processes rather than through spatial blueprints. It is important, however, that this is not a closed process, which takes place at the start of a group's lifespan, but remains open to changing needs and desires. This requires a critical ongoing dialogue between utopian social theory and autonomous practices.

\section{Acknowledgements}

Thanks are due to Andrew Robinson, Lucy Sargisson and Gulshan Khan of the Department of Politics and International Relations at the University of Nottingham, as well as the two anonymous reviewers, who have all read and offered useful comments on draft versions of this article. An early version of this paper was presented at the Spaces of Alterity conference at the University of Nottingham in April 2011 and I am grateful to the attendees for their questions and comments. Thanks also to Örjan Sjöberg and Guy Baeten at the journal for their encouragement and editorial input. The fieldwork referred to herein was undertaken during my $\mathrm{PhD}$ project which was funded by the ESRC $1+3$ scheme. 


\section{Rhiannon Firth}

Department of Politics and International Relations

University of Nottingham

University Park

Nottingham NG7 2RD

United Kingdom

Email: rhiannonfirth@gmail.com 


\section{References}

ABRAMS, P. and MCCULLOCH, A. (1976): Communes, Sociology and Society. Cambridge University Press, Cambridge.

AMIN, A. and MALMBERG, A. (1994): 'Competing structural and institutional influences on the geography of production in Europe', in AMIN, A. (ed.): Post-Fordism: A Reader. Blackwell, Oxford, pp. 227-248.

AMSTER, R. (2009): 'Anarchy, utopia, and the state of things to come', in AMSTER, DELEON, A., FERNANDEZ, L. A., NOCELLA, A. J., II and SHANNON, D. (eds): Contemporary Anarchist Studies: An Introductory Anthology of Anarchy in the Academy. Routledge, London, pp. 290-301.

ANDERSON, B. (2006): 'Becoming and being hopeful: towards a theory of affect', Environment and Planning D: Society and Space 24 (5): 733-752.

ANDREOTTI, L. (1996): 'Introduction: the urban politics of the internationale situationniste (19571972)', in ANDREOTTI, L. and COSTA, X. (eds): Situacionistas: Arte, Politica, Urbanismo / Situationists: Art, Politics, Urbanism. Museu d'Art Contemporani de Barcelona, Barcelona, pp. 11-39.

ANON (1999): 'Desire is speaking: utopian ehizomes', Do or Die 8: 137-140.

ANON (2001): Brittle Utopias, retrieved July 22, 2009 from Killing King Abacus: http://www.reocities.com/kk_abacus/kka/UTOPIAS.html.

AUGÉ, M. (1995): Non- Places: Introduction to an Anthropology of Supermodernity, New York: Verso.

BAETEN, G. (2002): 'Western utopianism/dystopianism and the political mediocrity of critical urban research', Geografiska Anneler. Series B, Human Geography 84 (3-4): 143-152.

BAKHTIN, M. (1984): Problems of Dostoevsky's Poetics. University of Minnesota Press, Minneapolis, MN.

BAUMAN, Z. (1976): Socialism, the Active Utopia. George Allen \& Unwin, London.

BELL, D. (2010): 'Fail again. Fail better: nomadic utopianism in Deleuze \& Guattari and Yevgeny Zamyatin', Political Perspectives 4 (1): http://www.politicalperspectives.org.uk/2010/08/volume-4issue-1/ [accessed 30 December 2011]

BERNERI, M. L. (1950): Journey through Utopia. Schocken, New York.

BEY, H. (1985): TAZ: The Temporary Autonomous Zone, Ontological Anarchy, Poetic Terrorism, Autonomedia, Brooklyn, NY.

BEY, H. (1993): 'Permanent TAZs', The Hermetic Library [online document]. URL http://www.hermetic.com/bey/paz.html [accessed 5 May 2009]. 
BLACK, B. (1997): Anarchy after Leftism. CAL Press, Columbia, MO.

BLOCH, E. (1986): The Principle of Hope, Vols 1-3. Blackwell, Oxford.

BONANNO, A. M. (1988): Propulsive Utopia. Elephant Editions, London.

BOOKCHIN, M. (1974): The Limits of the City. Harper Colophan, New York.

BOOKCHIN, M. (1992): Urbanization without Cities: The Rise and Decline of Citizenship. Black Rose, Montreal, QC.

BUBER, M. (1951): 'Society and the state', World Review NS 27 (May): 5-12.

BUBER, M. ([1949] 1996): Paths in Utopia. Syracuse University Press, Syracuse, NY.

CASTELLS, M. ([1972] 2002): 'The urban ideology', in SUSSER, I. (ed.): The Castells Reader on Cities and Social Theory. Blackwell, Malden, MA, pp. 34-70.

CASTELLS, M. ([1978] 2002): 'Collective consumption and urban contradictions in advanced capitalism', in SUSSER, I. (ed.): The Castells Reader on Cities and Social Theory. Blackwell, Malden, MA, pp. 107-129.

CASTELLS, M. (1978): City, Class and Power. Macmillan, London.

CHAT'TERTON, P. and HODKINSON, S. (2007): 'Why we need autonomous spaces in the fight against capitalism', in THE TRAPESE COLLECTIVE (eds): Do It Yourself: A Handbook for Changing our World. Pluto Press, London, pp. 201-215.

CLASTRES, P. (1977): Society against the State. Blackwell, Oxford.

DAVIS, K. ([1965] 1996): The urbanization of the human population, in LeGATES, R.T. and STOUT, F.: The City Reader. Routledge, London, pp. 20-30

DAY, R. J. F. (2005): Gramsci is Dead: Anarchist Currents in the Newest Social Movements. Pluto Press, London.

DEBORD, G. (2002): Society of the Spectacle. Rebel Press, London.

DELEUZE, G. ([1983] 2006 ): Nietzsche and Philosophy. Continuum, London.

DELEUZE, G. and GUATTARI, F. (1988): A Thousand Plateaus: Capitalism and Schizophrenia. Continuum, London.

DELEUZE, G. and GUATTARI, F. (2004): Anti- Oedipus. Continuum, London.

FIRTH, R. (2011): Utopian Politics: Citizenship and Practice. Routledge, London. 
GARDINER, M. (2004): 'Everyday utopianism: Lefebvre and his critics', Cultural Studies 18 (2-3): 228254.

GARFORTH, L. (2009): 'No intentions? Utopian theory after the future', Journal for Cultural Research 13 (1): 5-27.

GARNER, R. (2000): Environmental Politics: Britain, Europe and the Global Environment. Macmillan, Basingstoke.

GOTTMAN, J. (ed.) (1980): Centre and Periphery: Spatial V ariation in Politics. Sage, Beverly Hills, CA.

HANNERZ, U. (1990): 'Cosmopolitans and locals in world culture', Theory, Culture and Society 7 (2): 237 251.

HARVEY, D. (1996): Justice, Nature, and the Geography of Difference. Blackwell, Oxford.

HARVEY, D. (2000): Spaces of Hope. University of California Press, Berkeley, CA.

HODKINSON, S. and CHATTERTON, P. (2006): 'Autonomy in the city? Reflections on the social centres movement in the UK', City 10 (3): 305-315.

HOPKINS, R. (2008): The Transition Handbook: From Oil Dependency to Local Resilience. Green Books, Totnes.

HORROX, J. (2009): A Living Revolution: Anarchism in the Kibbutz Movement. AK Press, Edinburgh.

HOWARD, E. ([1902] 1996): 'Extracts from Garden Cities of To-morrow', in LEGATES, R. T. and STOUT, F. (ed.): The City Reader. Routledge, London, pp. 346-353.

ILLUMINATI, A. (1996): 'Unrepresentable citizenship', in VIRNO, P. and HARDT, M. (eds): Radical Thought in Italy: A Potential Politics. University of Minnesota Press, Minneapolis, MN, pp. 166-186.

ISIN, E. F. (1997): 'Who is the new citizen? Towards a genealogy', Citizenship Studies 1 (1): 115-132.

ISIN, E. F. (2000): 'Governing cities without government', in ISIN, E. F. (ed.): Democracy, Citizenship and the Global City. Routledge, London, pp. 148-167.

ISIN, E. F. (2007): 'City.State: critique of scalar thought', Citizenship Studies 11 (2): 211-228.

JURIS, J. S. (2008): Networking Futures: The Movements against Corporate Globalisation. Duke University Press, Durham, NC.

KANTER, R. M. (1972): Commitment and Community: Communes and Utopias in Sociological Perspective. Harvard University Press, Cambridge, MA. 
KARATZOGIANNI, A. and ROBINSON, A. (2010): Power, Resistance and Conflict in the Contemporary World: Social Movements, Networks and Hierarchies. Routledge, London.

KATSIAFICAS, G. (2006): The Subversion of Politics: European Autonomous Movements and the Decolonization of Everyday Life. Updated edn, AK Press, Edinburgh.

KRAFTL, P. (2007): 'Utopia, performativity, and the unhomely', Environment and Planning D: Society and Space 25 (2): 120-143.

KRAFTL, P. (2008): 'Young people, hope, and childhood-hope', Space and Culture 11 (2): 81-92.

KROPOTKIN, P. A. ([1899] 1913): Fields, Factories and Workshops: Industry Combined with Agriculture and Brain Work with Manual Work, $2^{\text {nd }}$ edn., G. P. Putnam's Sons: New York and London: http://www.archive.org/details/fieldsfactoriesw00kropiala [accessed 30 December 2011.

KROPOTKIN, P. A. ([1896] 1970): 'The state: its historic role', in MILLER, M. A. (ed.): Selected Writings on Anarchism and Revolution. MIT Press, Cambridge, MA, pp. 211-264

LANDAUER, G. ([1911] 1978): For Socialism. Telos, St Louis.

LEFEBVRE, H. (1991): The Production of Space. Blackwell, Oxford.

LEVITAS, R. (1990): The Concept of Utopia. Syracuse University Press, Syracuse, NY.

MARX, K. and ENGELS, F. ([1846] 1998): The Communist Manifesto. Merlin, London.

MAY, T (1994): The Political Philosophy of Poststructuralist Anarchism. Pennsylvania State University, University Park, PA.

MCKAY, G. (1996): Senseless Acts of Beauty: Cultures of Resistance since the Sixties. Verso, London.

McMANUS, S. (2005): Fictive Theories: Toward a Deconstructive and Utopian Political Imagination. Palgrave Macmillan, New York.

MEIJERING, L., HUIGEN, P. and van HOVEN, B. (2007): 'Intentional communities in rural spaces', Tijdschrift voor Economische en Sociale Geografie 98 (1): 42-52.

MORE, T. ([1516] 2004): Utopia. Penguin, London.

MOYLAN, T. (1986): Demand the Impossible: Science Fiction and the Utopian Imagination. Methuen, New York. PEPPER, D. (1991): Communes and the Green Vision: Counterculture, Lifestyle and the New Age. Green Print, London.

PEREZ, R. (1990): On An(archy) and Schiroanalysis. Autonomedia, New York. 
PICKERILL, J. and CHATTERTON, P. (2006): 'Notes towards autonomous geographies: creation, resistance and self-management as survival tactics', Progress in Human Geography 30 (6): 730-746.

PINDER, D. (2002): 'In defence of utopian urbanism: imagining cities after the "end of utopia", Geografiska Annaler: Series B, Human Geography 84 (3-4): 229-241.

PLANT, S. (1992): The Most Radical Gesture: The Situationist International in a Postmodern Age. Routledge, London.

RIGBY, A. (1974): Alternative Realities: A Study of Communes and their Members. Routledge and Kegan Paul, London.

ROBINSON, A. and TORMEY, S. (2009): 'Utopias without transcendence? Post-left anarchy, immediacy and utopian energy, in HAYDEN, P. and EL-OJEILI, C. (eds): Globalization and Utopia: Critical Essays. Palgrave Macmillan, Basingstoke, pp. 156-175

ROBINSON, J. (2006): Ordinary Cities: Between Modernity and Development. Routledge, London.

SARGENT, L. T. (1994): 'The three faces of utopianism revisited', Utopian Studies 5 (1): 1-37.

SARGISSON, L. (1996): Contemporary Feminist Utopianism. Routledge, London.

SARGISSON, L. (2000): Utopian Bodies and the Politics of Transgression. Routledge, London.

SARGISSON, L. (2001): 'Politicising the quotidian', Environmental Politics 10 (2): 68-89.

SARGISSON, L. and SARGENT, L. T. (2004): Living in Utopia: New Zealand's Intentional Communities. Ashgate, Aldershot.

SASSEN, S. (2006): Territory, Authority, Rights: From Medieval to Global Assemblages. Princeton University Press, Princeton, NJ.

SASSEN, S. (2005): 'The repositioning of citizenship and alienage: emergent subjects and spaces for politics', Globalizations 2 (1): 79-94.

STIRNER, M. ([1844] 1993): The Ego and Its Own. Rebel Press, London.

TAYLOR, K. (2003): 'Utopianism', in MCLEAN, I. and MCMILLAN, A. (eds): Oxford Concise Dictionary of Politics. Oxford University Press, Oxford, pp. 554-556.

TESTER, K. (1994): 'Introduction', in TESTER, K. (ed.): The Flâneur. Routledge, London, pp. 1-21

THE INVISIBLE COMMITTEE (2009): The Coming Insurrection. Semiotext(e), New York.

THE RED SUNSHINE GANG ([c. 1970] 1999): Anti-Mass: Methods of Organization for Collectives. Kersplebedeb, Montreal, QC. 
UNSIGNED (1959): 'Unitary urbanism at the end of the 1950s', Situationist International online [online document]. URL http://www.cddc.vt.edu/sionline/si/unitary.html [accessed 30 December 2011].

VANEIGEM, R. ([1967] 2006): The Revolution of Everyday Life. Rebel Press, London.

VEYSEY, L. (1978): The Communal Experience: Anarchist and Mystical Communities in Twentieth-century America. University of Chicago Press, Chicago.

VIRILIO, P. (1986): Speed and Politics: An Essay on Dromology. Semiotext(e), New York.

VIRNO, P. (1996): 'Virtuosity and revolution: the political theory of exodus', in VIRNO, P. and HARDT, M. (eds.): Radical Thought in Italy: A Potential Politics. University of Minnesota Press, Minneapolis, MN, pp. 189-209.

WARD, C. (1973): Anarcby in Action. Allen and Unwin, London.

WARD, C. (2002): Cotters and Squatters: The Hidden History of Housing. Five Leaves, Nottingham.

WEBBER, E. (1959): Escape to Utopia: The Communal Movement in America. Hastings House, New York. 